\title{
Intercropping Induce Changes in Above and Below Ground Plant Compartments in Mixed Cropping System
}

\author{
Jamal Nasar*1, Ashfaq Alam², Aisha Nasar ${ }^{3}$ and Muhammad Zubair Khan ${ }^{4}$ \\ ${ }^{1}$ College of Resources and Environmental Sciences, China \\ ${ }^{2}$ Department of Horticulture, Pakistan \\ ${ }^{3}$ Government Degree College, Pakistan \\ ${ }^{4}$ College of agronomy, China \\ *Corresponding author: Jamal Nasar, College of Resources and Environmental Sciences/Key Laboratory of Sustainable Utilization \\ of Soil Resources in the Commodity Grain Bases in Jilin Province, Jilin Agricultural University, Changchun 130118, China
}

\begin{tabular}{|c|c|}
\hline ARTICLE INFO & ABSTRACT \\
\hline Received: 幽 April 29, 2019 & \multirow{4}{*}{$\begin{array}{l}\text { Crops growing in a mixture is an ancient agricultural practice and usually been } \\
\text { used for improving yield and growth of the crops and to fulfill the world fast growing } \\
\text { population food demand. The two crops growing on same soil zone may be in direct } \\
\text { competition to utilize the available resources because planting plants on same land using } \\
\text { the same resources for normal growth. In intercropping system there may be facilitative } \\
\text { and competitive interaction among the plants in both above and below ground plants } \\
\text { compartments. The intension of intercropping is to utilize the use of physical, temporal } \\
\text { and spatial resources both above and below ground plant compartments by maximizing } \\
\text { the complementary interaction and minimizing the competitive ones. The changes and } \\
\text { complex interaction both in upper and underground plant parts in inter-cropping system } \\
\text { those adopted by local farmers in China are not yet fully understood. Information's from } \\
\text { such studies are likely to provide knowledge about the complex interactions among two } \\
\text { crops growing in a mixture. This study was therefore assessed to perceive how plants in } \\
\text { mixture change the above below ground compartments and how they interact. }\end{array}$} \\
\hline Published: 㓞 May 07, 2019 & \\
\hline $\begin{array}{l}\text { Citation: Jamal Nasar, Ashfaq Alam, } \\
\text { Aisha Nasar, Muhammad Zubair Khan. } \\
\text { Intercropping Induce Changes in Above } \\
\text { and Below Ground Plant Compartments } \\
\text { in Mixed Cropping System. Biomed } \\
\text { J Sci \& Tech Res 17(5)-2019. BJSTR. } \\
\text { MS.ID.003054. }\end{array}$ & \\
\hline $\begin{array}{l}\text { Keywords: Complementary; Competi- } \\
\text { tions; Mixed Cropping; Intercropping }\end{array}$ & \\
\hline
\end{tabular}

\section{Introduction}

Intercropping is an old cropping system which dates back to ancient civilization and practice globally to achieve more yields and to satisfy the world food demand [1-6]. Mix cropping system not only enhance crop production and returns but can help safe the plants from complete failure as compare to mono-cropping [2]. The purpose of intercropping is to efficiently utilize the available plant growth resources like water [3], nutrients [4], and sun light and to minimize the competition and control weeds, disease and pest incidences [5]. The facilitations occurs both above and below ground plant compartments when plants using the same soil zone $[7,8]$. Cereal-legumes intercropping is common cropping system in which cereal get growth and yield advantages from legumes by sharing nutrients and some other unknown resources $[1,9]$. It is well known that plants growing in mixture interact with each both positively and negatively in the above and below ground plant compartments. The above plants facilitative integrations are well investigated, however what's going inside in the below ground plants-soil and plant-plant in mix cropping system are still not clear [9-11]. Rhizospheric plant roots, soil and microbial interactions are beneficial to plant ecosystem. Rhizosphere root exudations process play a vital role in plant nutrition $[12,13]$.

To date, the below ground interactions in intercropping and its effect on plant growth acquired a little attention [9-11]. To achieve greater yield, improve rhizospheric microbial conditions, soil quality betterment, resources utilization, soil nutrients recycling, proper management practices require in mixed cultures [14]. Though 
cereals and legumes grown singly are highly investigated but few researches are available on the complex mixed cropping system specially on the below ground plant compartments (rizhosphere interactions), hence more studies are require explore the fact about rhizospheric soil in intercropping [9]. The intension of growing plants in a mixture is to efficiently utilize facilitative (positive interactions) resources and curtail competitions both in the above and underground plant compartments [15-22]. insufficient literatures are available on the on the below ground mechanism involved in mix cropping system those practice by traditional farmers $[9,11]$ because it's complexity in mixed cropping system rhizosphere. This study is therefore design to collect information for understanding above and below ground interaction in crop mixtures (Figure 1).

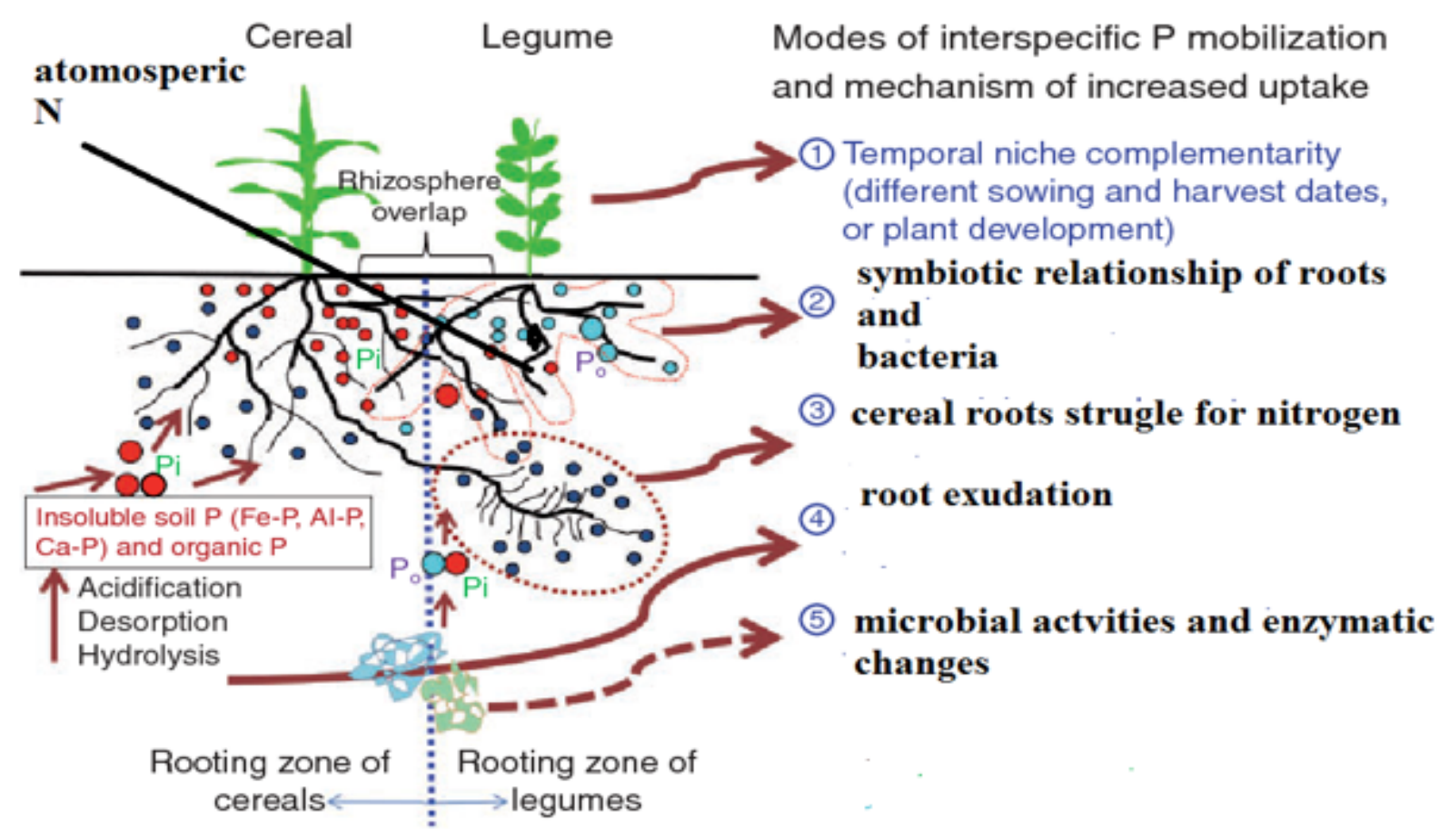

Figure 1: Nitrogen fixation, transfer and the role of microorganisms in cereal legumes intercropping system (Xue et al. 2016).

\section{Plant to Plant Interaction in Intercropping}

Plants intract with each other in mixed cropping system for improving their growth and yield. However, little knowledge is available plants interactions growing in mixture, particularly in cereal/legumes mixture [23]. For instance, the interspecific interactions both facilitative and competitive contribute to high yielding [23]. However, the below-ground root interactions are highly responsible for yield betterment [23]. In mixed cropping system, crops will be in direct competitions while capturing the same resources. Whereas, the differences can only occur in phonological characteristics which results improving limited plant growth resources among plants species [15-20,22] and maximize plant productiveness when compare to single culture $[15,16,24$ 32]. Hence, legumes/cereal mixture interactions (facilitative \& competitive) are complicated to examine [33-36] in utilization and modification of natural resources further research are require to address the interactions (above \& below ground) in traditional cropping mixture.

\section{Rhizospheric interaction in intercropping}

In intercropping system both plant species uses the same soil zone for root resources which directly associated with growth performance [16,37-39]. Under such situations, roots nutrients competitions are frequently happen. Previously documented that the below ground activities in maize/cowpea mixture occur at a soil depth of $30-45 \mathrm{~cm}$ and at more depth shows decreased in theirs densities [40]. As a result significantly higher yield was recorded in maize crop than cowpea [26]. Apart from that side effect on plant yield, plant and soil were positively affected by mixed cropping roots system, for example increased the availability of carbon through $\mathrm{C}$ transformation [41,42], phonolics discharge, root exudates (phyosiderophores and carboxylic acids) in plant parts $[12,13]$.

These elements are responsible for plants mineral nutrition. Additionally several research on the low phosphorous soil has shown that plant roots (pigeon pea) use piscidic, malonic and oxalic acid to solubilize iron, calcium, and Al-bond P [43]. Once phosphorous and iron mobilized, readily available for plant 
acquisition and available for microorganisms in an intercropping Similarly buckwheat roots discharge oxalate as an Al-oxakate in $\mathrm{Al}$ toxic soil which change Aluminum to plants and microorganisms available form in mixed cropping [44]. Under such circumstances crop productiveness can be increased when grown in a mixture. Similar activities in underground plant parts are occur in all intercropping system use by all farmers. Although there has been relatively little research on below ground activities in crop mixture so more studies are need to be established. So far the competition among plants for utilizing light and water resources has been studied earlier but research on nutrients competition in cropping mixture are rare [8-11]. Thus, more experiments are suggested to investigate more about the nutrient competitions between plants in cereal/legumes mixture (Figure 2).

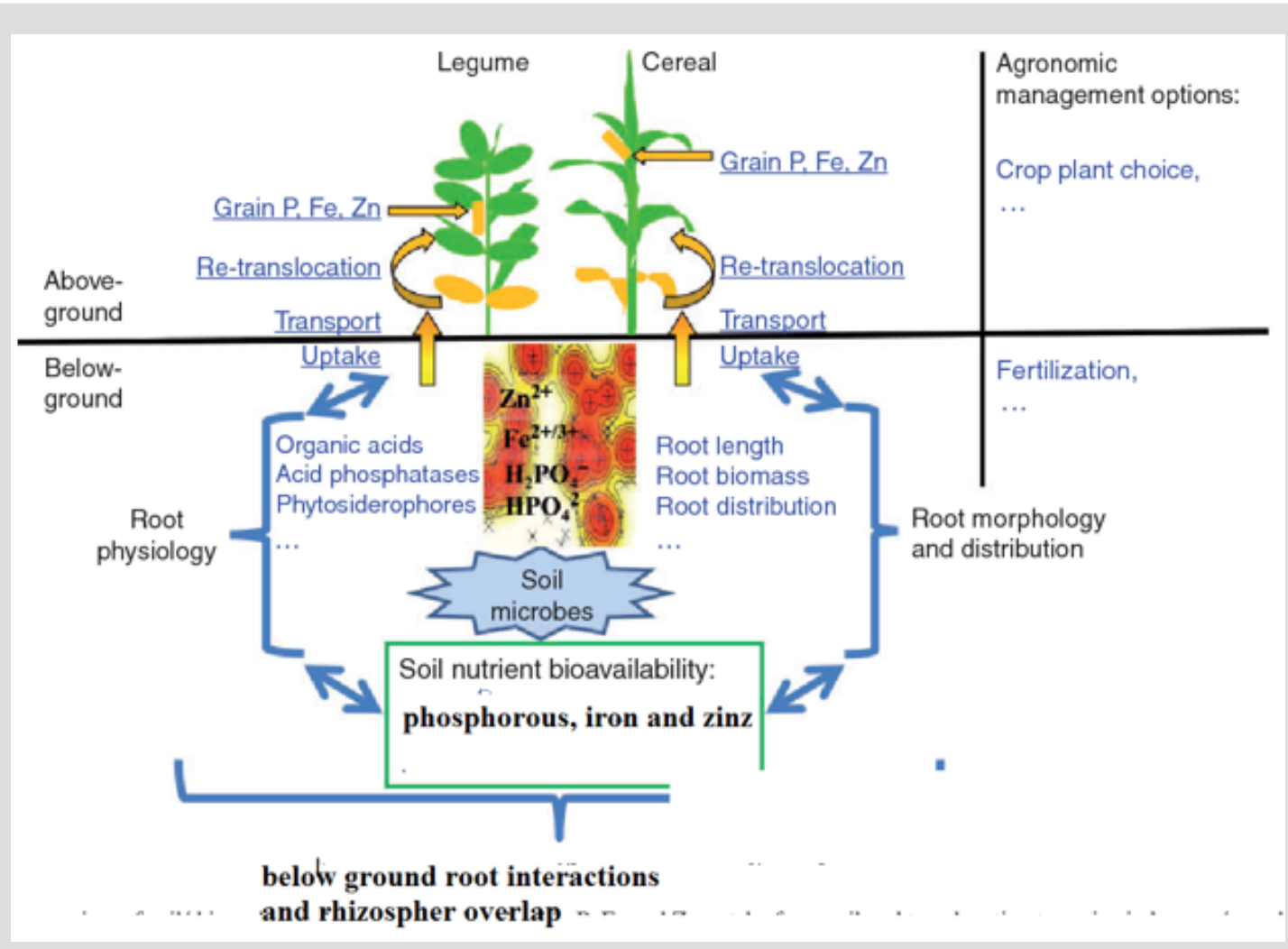

Figure 2: The fig shows the below ground interspecific root interaction, rhizhospheric changes, nutrients transport, uptake and facilitation in intercropping system (Xue et al. 2016).

\section{Rhizospheric $\mathrm{pH}$ Changes in Intercropping System}

Several plants have the capability to change their rhizospheric soil $\mathrm{pH}[12,45-49]$ and convert $\mathrm{P}, \mathrm{K}, \mathrm{Ca}$, and $\mathrm{Mg}$ to available form, $[7,50]$. For example many reactions occur in the rhizosphere of leguminous crop which can definitely affect the plants nutrients uptake and acquisition [51-53]. As previously, [54] documented that as the rhizospheric soil $\mathrm{pH}$ changes the plant nutrients availability was increased up to $45-120 \%$ P, $108-161 \% \mathrm{~K}, 120$ $148 \% \mathrm{Ca}, 127-225 \% \mathrm{Mg}$ and $117-250 \% \mathrm{~B}$ in cropping mixture (tea/ Cyclopia genistoids) in South Africa. Hence, in balancing internal processing pluses may absorb more base cations and release $\mathrm{H}^{+}$ to rhizospheric soil that results in soil acidification [12,51-53,55]. Various leguminous crop like alfalfa, cowpea, lupine and chickpea can lower their rhizospheric soil $\mathrm{pH}$ because of releasing some considerable amount of organic anions [56-62] and enhance the organic P availability to plants and soil microorganisms. Similarly white lupine (lupinus albus) in sole cropping can lower their rhizospheric soil $\mathrm{pH}$ due to the release of organic anions and proton which recovered considerable amount of $\mathrm{P}$ from soil and increased its availability to next crop (wheat) [63,64]. Likewise, peagon pea when intercropped with sorghum increased $\mathrm{P}$ uptake by exuding piscidic acid anions that chelated $\mathrm{Fe}^{3+}$ and subsequently released $\mathrm{P}$ from $\mathrm{FePO}_{4}$ [43]. In field trial, maize $\mathrm{P}$ concentration can be improved by intercropped with faba bean [8,65-67]. In contrast, chickpeas has the potential to mobilize organic P proved to be superior to that of corn due to greater exudation of protons and organic acids by chickpea compared to maize [62]. Hence, plants in a mixture those cereals do not have strong rhizhosphere acidification and can dependent directly on legumes root exudates for nutrients solubilization. It is however not clear that what changes the rhizosphere $\mathrm{pH}$ in mix culture those involving legumes and cereal and their effect on different soil chemical and biological reactions.

\section{$\mathrm{N}_{2}$ fixation, $\mathrm{N}$ Uptake and $\mathrm{N}$ Transfer in Cereal/Legumes Intercropping}

Nitrogen is key element required for plants normal growth and productivity. More research are available on the biological 
$\mathrm{N}$ fixation in grain legumes [35,68-70] because of legumes are able to acquire almost $75 \%$ of their nitrogen requirement from atmosphere [71,72]. Nevertheless, less study on the biological nitrogen fixation in cereal/legumes mixture are available $[70,73]$. More specifically, the cropping mixture typically exhibits nutrients advantage [74,75]. Nitrogen uptake in mix cropping system enhances the nutrients status of associated crops. This $\mathrm{N}$ facilitation in intercropping system may be due to that, leguminous crops obtain $\mathrm{N}$ through biological nitrogen fixation which then available or transfer to associated cereal crop by direct root contact or exudation and mycorrhizal association and thus improve the $\mathrm{N}_{2}$ fixation ability of legumes [76]. it is well know that intercropping cereal with legumes under low fertilization improve the $\mathrm{N}$ nutrient in cereal and thus overyield [50].

Previously documented that different cropping system like wheat/soybean, maize/faba bean, barley/pea and sorghum/ soybean significantly increased the $\mathrm{N}$ acquisition compare to sole cropping system [77-79]. The atmospheric $\mathrm{N}$ taken up by faba bean was increased $8 \%$ to $33 \%$ (early flowering stage), 54\%-61\% (full flowering stage),18\%-50\% (grain-filling stage), and up to $72 \%$ (full maturity stage) than monocropped faba bean [80]. The ${ }^{15} \mathrm{~N}$ labeling techniques are using for direct transfer of $\mathrm{N}$ from legumes to neighboring non-legume plant in intercropping system, legumes are the dominant crop for fixing atmospheric nitrogen which is beneficial to the system $[20,81]$, increase the $\mathrm{N}$ uptake in cereal and thus yield. It is evident previously that nitrogen fixed by legumes can be significantly transferred to their associated non-legumes crop grown in a mixture $[68,69,73,82,83]$. Thereby increased the soil $\mathrm{N}$ content $[36,84,85]$. In mixed culture, planting legumes at long distance from non-legumes may lead to decreasing $\mathrm{N}$ transfer. In past researcher declared that $\mathrm{N}$ competition in legumes/cereal mixed culture may further be increase through nitrogen fixing activity by leguminous crops $[79,86]$. Cereal plants efficiently utilize soil $\mathrm{N}$ which results more $\mathrm{N}$ fixation in legumes. It is therefore an important study to expose the effect of planting mixtures on biological nitrogen fixation and nutrition.

\section{Soil Microbial Biomass in Intercropping}

Microbial biomass in plants mixture is influence by various physio-chemical and biological characteristics those involve in an intercropping system. In general, soil microbial $\mathrm{C}$ is highly affected by different agricultural practices [87-89]. For example, the farm-land and grass land found to be higher in soil microbial C than uncultivated lands $[87,90]$. Intercropping in comparison with single cropping is expected more suitable cropping pattern for increasing soil microbial biomass. The intercropping of durum wheat with legumes like chickpea, lentil increased the soil microbial biomass [91]. Studies on the legumes has shown that these plants are capable to increase soil microbial $C$ than cereal [92], tend to reduce carbon to nitrogen ratio in legumes compare to cereals. The microbial biomass activities can further be increase by adding any energy sources to soil. Higher microbial biomass activities can be expected in soil by natural manuring than commercial fertilization [93,94]. Soil microbial biomass activity and organic matter are responsible factors for improving soil nutrients status, fertility and productiveness and can be enhanced by additional organic sources incorporated to the soil $[93,94]$. Under sufficient application of P, the soil microbial biomass can be boost in a result plant growth and soil organic matter can also be improve [93]. The biological soil activity in legumes/cereal mixture results in improving soil organic substrates utilizing by soil micro flora need more research attention. Although soil-microbes relationship has been considerable investigated but few literature are available on such studies those practice in humid regions [95]. In this prospective, useful information can acquire by measuring these activities in a relation to soil health in diverse cropping system.

\section{Phosphatase Activity, P Acquisition and P Uptake in Intercropping}

Intercropping can improve the P uptake under P deficient soil $[43,63,96]$. Soil contains phosphorous mostly in organic which cannot directly taken up by the plant [97]. Plants can acquire the phosphorus after hydrolyzed by below ground microbes and phosphotase activities release by plant roots. Different biochemical processes and release of carboxylates, protons and enzymes from the roots of P-moblizing plants can mobilize the organic and immobilize $P$ and benefit the non-P moblizing crops in mix cropping culture [98]. In P-impoverished soil, some species form dauciform roots or cluster roots [98]. It reviewed earlier that Dauciform roots or cluster roots exude carboxylates and mobilize soluble $\mathrm{P}$ in soil increased $\mathrm{P}$ acquisition and supply $\mathrm{P}$ to neighbor plant in inter-crop [99]. Numerous studies have shown P use efficiency in inter-rhizosphere those of cereal and legumes. The P-moblizing crop promisingly improved the phosphorous acquisition of cereal when inter cropped together $[44,96]$. Chickpea P facilitation for its associated intercrop plant are more prominent because of its high release rhizospheric acid phosphatases which convert organic P to inorganic [34]. Faba bean can facilitate its neighboring plants with $\mathrm{P}$ by mobilizing $\mathrm{P}$ through release of protons, malate and citrate into the rhizosphere. The efficient utilization of phosphorous in intercropping sytem helps reducing the in-P fertilization in agroecosytem [96].

The root exudation in mixed cropping system improve the Piscidic acid, citrate, protons and acid phosphatase activities which helping in $\mathrm{P}$ mobilization and thus $\mathrm{P}$ acquisition by neighboring plant (cereals) $[43,63,96,100]$. The inter-rhizospher processes possibly facilitate the $\mathrm{P}$ to associated cereal in intercropping system [101]. Previously demonstrated that P concentrations both in above shoot and below roots and plants $\mathrm{P}$ utake were increased when maize were intercropped with faba bean $[34,98]$. Crops can survive under low phosphate availability because of different enzymatic and morphological abilities conversion of phosphtases which tend to increase in $\mathrm{P}$ starvation condition [102-109] but low $\mathrm{P}$ availability adversely affect the $\mathrm{N}_{2}$ fixation in legumes. 
Phosphatese enzyme is a key factor involving in soil fertility and performs different functions [110-112]. This enzyme is more likely to increase in low P soils [59,113-116], a comparative research on the acid phosphotase activity in white lupin root growing in high and low phosphorus soils show that acid phosphotase activity both in root extracts and root exudates in low P soil were significantly higher. Under different stress level these phosphatase enzyme are able to releae phosphate from cells $[104,117]$. The increasing rate of $\mathrm{P}$ transportation in P-deficient plant is because to remobilize and optimize P uptake [118-130]. These enzymatic and completion of $\mathrm{P}$ starvation are considered to be managed by common P stressrelated and specific signaling system.

The secreted plant acid phosphate amount is genetically controlled; differ at plant to plant [124] and various cropping techniques [126-127]. Different experimental results showed that legumes plants discharge more enzymes compare to grain crop as for instance [128] in their experiment observed that the enzyme secretion by legumes was $72 \%$ higher than that of cereals. The amount of enzyme secrete by chickpea root was higher than maize plant [62]. In biological manage system phosphate activity expected to be higher because of high carbon present in the system. As these activity of was found to be correlated with OM in different studies $[129,130]$. Hence mix cropping practices is expected to induce P-stress in the rhizosphere, in a result different enzymes excretion may be occur. Till now a little research on the impact of mix cropping system on phosphatase activity in the rhizosphere are available. It is crucial to understand the rhizosphere enzyme activities, nutrients acquisitions by such activities and their effect on the plants growth and yield in mix cropping system.

\section{Conclusion}

The interspecific interactions among crops in intercropping system provide facilitative interaction both in upper and underground plant ecosystems which contribute promote crop productivity and nutrients acquisitions. More ever the below ground interactions in mixed cropping system play better role than above interactions. For better crop productivity and growth improvement future research should focus on the below ground plants roots, soil and microbial interactions those involve in mix cropping system. Studies on the micronutrients acquition in intercropping system are less available so such research are encourage to investigate the micronutrients acquision, transformation and uptake in both above and below ground plant parts and the role rhizpheric microbial community.

\section{References}

1. Vandermeer J (1990) Intercropping. Intercropping 481-516.

2. Zhang F, Li L (2003) Using competitive and facilitative interactions in intercropping systems enhances crop productivity and nutrient-use efficiency. Plant and soil 248: 305-312.

3. Connolly J, HC Goma, K Rahim (2001) The information content of indicators in intercropping research. Agriculture, ecosystems \& environment 87(2): 191-207.
4. Zhang F, Wenxue Li, Long Li (2003) Do interspecific interactions reduce phosphorous fertilizer rates in the faba bean/maize intercropping. In Proceedings of 2 nd International Symposium on phosphorous dynamics in the soil plant continuum 26(3): 21-26.

5. Zhang F (2004) An overview of rhizosphere processes related with plant nutrition in major cropping systems in China. Plant and Soil 260(1-2): 89-99.

6. Dakora FD, Phillips DA (2002) Root exudates as mediators of mineral acquisition in low-nutrient environments. In Food Security in NutrientStressed Environments: Exploiting Plants' Genetic Capabilities 201-213.

7. Dakora FD (2003) Defining new roles for plant and rhizobial molecules in sole and mixed plant cultures involving symbiotic legumes. New Phytologist 158: 39-49.

8. Juma N (1996) Crop yield and soil organic matter trends over 60 years in a Typic Cryoboralf at Breton, Alberta. Soil Organic Matter in Temperate Agroecosystems 273-281.

9. Mead R, Willey R (1980) The concept of a 'land equivalent ratio'and advantages in yields from intercropping. Experimental Agriculture 16: 217-228.

10. Horwith B (1985) A role for intercropping in modern agriculture. Bio Science 35(5): 286-291.

11. Ofori F, Stern W (1987) Cereal-legume intercropping systems. In Advances in agronomy 41-90.

12. Willey R, Osiru D (1972) Studies on mixtures of maize and beans (Phaseolus vulgaris) with particular reference to plant population. The Journal of Agricultural Science 79: 517-529.

13. Willey RW (1979) Intercropping-its importance and research needs. Part 2. agronomy and research approaches.

14. Ofori F, Stern W (1986) Maize/cowpea intercrop system: effect of nitrogen fertilizer on productivity and efficiency. Field Crops Research 14: $247-261$.

15. Jose S, AR Gillespie, JR Seifert, DB Mengel, PE Pope (2000) Defining competition vectors in a temperate alley cropping system in the midwestern USA: 3. Competition for nitrogen and litter decomposition dynamics. Agroforestry Systems 48(1): 61-77.

16. SILWANA TT, Lucas E (2002) The effect of planting combinations and weeding on the growth and yield of component crops of maize/bean and maize/pumpkin intercrops. The Journal of Agricultural Science 138: 193-200.

17. Wu K (2012) Above-and below-ground interspecific interaction in intercropped maize and potato: A field study using the 'target'technique. Field Crops Research 139: 63-70.

18. Tariah N, Wahua T (1985) Effects of component populations on yields and land equivalent ratios of intercropped maize and cowpea. Field Crops Research 12: 81-89.

19. Lawson T, Kang B (1990) Yield of maize and cowpea in an alley cropping system in relation to available light. Agricultural and Forest Meteorology 52(3-5): 347-357.

20. Watiki J, S Fukai, JA Banda, BA Keating (1993) Radiation interception and growth of maize/cowpea intercrop as affected by maize plant density and cowpea cultivar. Field Crops Research 35(2): 123-133.

21. Peter G, Runge Metzger A (1994) Monocropping, intercropping or crop rotation? An economic case study from the West African Guinea savannah with special reference to risk. Agricultural Systems 45: 123143.

22. Rao M, Mathuva M (2000) Legumes for improving maize yields and income in semi-arid Kenya. Agriculture, ecosystems \& environment 78(2): 123-137.

23. Pitan 00, Odebiyi J (2001) The effect of intercropping with maize on the level of infestation and damage by pod-sucking bugs in cowpea. Crop Protection 20(5): 367-372 
24. Dapaah H (2003) Yield stability of cassava, maize, soya bean and cowpea intercrops. The Journal of Agricultural Science 140: 73-82.

25. Myaka F (1995) Effect of time of planting and planting pattern of different cowpea cultivars on yield of intercropped cowpea and maize in tropical sub-humid environment. Tropical Science (United Kingdom).

26. Asafu Agyei J (1997) Sustaining food production in Ghana: the role of cereal/legume based cropping systems. Technology options for sustainable agriculture in sub-Saharan Africa, (Eds.). T Bezuneh, AM Emechebe, J Sedogo, M Ouedraogo, Semi-Arid Food Grain Research and Development Agency (SAFGRAD) of the Scientific, Technical and Research Commission of OAU, Ouagadougou, Burkina Faso, West Africa, pp. 409-416.

27. Izaurralde R (1990) Plant and nitrogen yield of barley-field pea intercrop in cryoboreal-subhumid central Alberta. Agronomy Journal 82: 295-301.

28. Long Li, Fusuo Zhang, Xiaolin Li, Peter Christie, Jianhao Sun, et al. (2003) Interspecific facilitation of nutrient uptake by intercropped maize and faba bean. Nutrient Cycling in Agroecosystems 65(1): 61-71.

29. Giller KE, Cadisch G (1995) Future benefits from biological nitrogen fixation: an ecological approach to agriculture. In Management of biological nitrogen fixation for the development of more productive and sustainable agricultural systems 74(1-2): 255-277.

30. Evans J, AM Mc Neill, MJ Unkovich, Neil Fettell (2001) Net nitrogen balances for cool-season grain legume crops and contributions to wheat nitrogen uptake: a review. Australian Journal of Experimental Agriculture 41: 347-359.

31. Chang J, Shibles RM (1985) An analysis of competition between intercropped cowpea and maize I. Soil $\mathrm{N}$ and $\mathrm{P}$ levels and their relationships with dry matter and seed productivity. Field Crops Research 12: 133-143.

32. Reddy K (1994) The effects of sole and traditional intercropping of millet and cowpea on soil and crop productivity. Experimental Agriculture 30(1): 83-88

33. Jensen JR (2003) Productivity in maize based cropping systems under various soil-water-nutrient management strategies in a semi-arid, alfisol environment in East Africa. Agricultural Water Management 59: 217-237.

34. Maurya P, Lal R (1981) Effects of different mulch materials on soil properties and on the root growth and yield of maize (Zea mays) and cowpea (Vigna unguiculata). Field Crops Research 4: 33-45.

35. De Ridder N, Van Keulen H (1990) Some aspects of the role of organic matter in sustainable intensified arable farming systems in the WestAfrican semi-arid-tropics (SAT). Fertilizer research 26(1-3): 299-310.

36. Vanlauwe B (1996) Residue Quality and Decompostion: An unsteady relationship?

37. Ae N, Arihara J, Okada K, Yoshihara T, Johansen C (1990) Phosphorus uptake by pigeon pea and its role in cropping systems of the Indian subcontinent. Science 248(4954): 477-480.

38. Ma JF (1998) High aluminum resistance in buckwheat: II. Oxalic acid detoxifies aluminum internally. Plant Physiology 117(3): 753-759.

39. HOFFLAND E (1989) Solubilization of rock phosphate by rape: I. Evaluation of the role of the nutrient uptake pattern. Plant and soil 113(2): 155-160.

40. Hoffland E (1992) Biosynthesis and root exudation of citric and malic acids in phosphate-starved rape plants. New Phytologist 122: 675-680.

41. Raven JA (1990) H+ extrusion and organic-acid synthesis in N2-fixing symbioses involving vascular plants. New Phytologist 114(3): 369-389.

42. Degenhardt J (1998) Aluminum resistance in the Arabidopsis mutantalr-104 is caused by an aluminum-induced increase in rhizosphere pH. Plant Physiology 117(1): 19-27.

43. Muofhe ML, Dakora FD (2000) Modification of rhizosphere $\mathrm{pH}$ by the symbiotic legume Aspalathus linearis growing in a sandy acidic soil.
Functional Plant Biology 27(12): 1169-1173.

44. Hauggaard Nielsen H, Jensen ES (2005) Facilitative root interactions in intercrops. In Root Physiology: from Gene to Function 237-250.

45. Jarvis S, Robson A (1983) The effects of nitrogen nutrition of plants on the development of acidity in Western Australian soils. I. Effects with subterranean clover grown under leaching conditions. Australian journal of agricultural research 34: 341-353.

46. Mc Lay C (1997) Acidification potential of ten grain legume species grown in nutrient solution. Australian Journal of Agricultural Research 48: $1025-1032$

47. Sas L (2001) Excess cation uptake, and extrusion of protons and organic acid anions by Lupinus albus under phosphorus deficiency. Plant Science 160(6): 1191-1198.

48. Dakora F (2000) Host-plant factors in the adaptation of indigenous African legumes to low pH soils. In Nitrogen fixation: from molecules to crop productivity 579-580.

49. Cheng Y (2004) Proton release by roots of Medicago murex and Medicago sativa growing in acidic conditions, and implications for rhizosphere $\mathrm{pH}$ changes and nodulation at low $\mathrm{pH}$. Soil Biology and Biochemistry 36(8): 1357-1365.

50. Dinkelaker B (1989) Citric acid excretion and precipitation of calcium citrate in the rhizosphere of white lupin (Lupinus albus L.). Plant, Cell \& Environment 12(3): 285-292.

51. Dinkelaker B (1995) Distribution and function of proteoid roots and other root clusters. Botanica Acta 108(3): 183-200.

52. Braum S, Helmke P (1995) White lupin utilizes soil phosphorus that is unavailable to soybean. Plant and Soil 176(1): 95-100.

53. Gilbert G (1999) Acid phosphatase activity in phosphorus-deficient white lupin roots. Plant, Cell \& Environment 22(7): 801-810.

54. Neumann G (1999) Physiological adaptations to phosphorus deficiency during proteoid root development in white lupin. Planta 208(3): 373382

55. RAO TP (2002) Regulation of rhizosphere acidification by photosynthetic activity in cowpea (Vigna unguiculata L. Walp.) seedlings. Annals of botany $89(2): 213-220$

56. Li SM (2004) Acid phosphatase role in chickpea/maize intercropping. Annals of Botany 94(2): 297-303.

57. Horst WJ, Waschkies, C. (1987) Phosphatversorgung von Sommerweizen (Triticum aestivum L.) in Mischkultur mit weisser Lupine (Lupinus albus L.). Zeitschrift für Pflanzenernährung und Bodenkunde 150(1): 1-8.

58. Kamh M (1999) Mobilization of soil and fertilizer phosphate by cover crops. Plant and Soil 211: 19.

59. Zhang F (2001) Contribution of above-and below-ground interactions to intercropping. In Plant Nutrition 978-979.

60. Li L (1999) Interspecific complementary and competitive interactions between intercropped maize and faba bean. Plant and Soil 212(2): 105114.

61. Li W (2003) Effects of nitrogen and phosphorus fertilizers and intercropping on uptake of nitrogen and phosphorus by wheat, maize and faba bean. Journal of plant nutrition 26(3): 629-642.

62. Eaglesham A (1981) Improving the nitrogen nutrition of maize by intercropping with cowpea. Soil Biology \& Biochemistry 13(2): 169-171.

63. Giller KE (1991) Nitrogen transfer from Phaseolus bean to intercropped maize measured using $15 \mathrm{~N}$-enrichment and $15 \mathrm{~N}$-isotope dilution methods. Soil Biology and Biochemistry 23: 339-346.

64. Peoples M (2002) Limitations to biological nitrogen fixation as a renewable source of nitrogen for agriculture.

65. Heichel G (1987) Legume nitrogen: symbiotic fixation and recovery by subsequent crops. Energy in world agriculture. 
66. Dakora F, Keya S (1997) Contribution of legume nitrogen fixation to sustainable agriculture in Sub-Saharan Africa. Soil Biology and Biochemistry 29(5-6): 809-817.

67. Stern W (1993) Nitrogen fixation and transfer in intercrop systems. Field crops research 34(3-4): 335-356.

68. Jose S (2004) Interspecific interactions in temperate agroforestry Agroforestry Systems 61(1-3): 237-255.

69. Thevathasan N, Gordon A (2004) Ecology of tree intercropping systems in the North temperate region: Experiences from southern Ontario, Canada. In New Vistas in Agroforestry 257-268.

70. Yuanmei Z (2015) Achieving food security and high production of bioenergy crops through intercropping with efficient resource use in China. Frontiers of Agricultural Science and Engineering 2: 134-143.

71. Li L (2001) Wheat/maize or wheat/soybean strip intercropping: I. Yield advantage and interspecific interactions on nutrients. Field crops research 71(2): 123-137.

72. Izaurralde R (1992) Nitrogen fixation efficiency, interspecies $\mathrm{N}$ transfer and root growth in barley-field pea intercrop on a Black Chernozemic soil. Biology and Fertility of Soils 13(1): 11-16.

73. Fujita K (1990) Nitrogen transfer and dry matter production in soybean and sorghum mixed cropping system at different population densities. Soil Science and plant nutrition 36(2): 233-241.

74. Li YY (2009) Intercropping alleviates the inhibitory effect of $\mathrm{N}$ fertilization on nodulation and symbiotic N 2 fixation of faba bean. Plant and Soil 323(1-2): 295-308.

75. Cochran VL, Schlentner SF (1995) Intercropped oat and fababean in Alaska: Dry matter production, dinitrogen fixation, nitrogen transfer and nitrogen fertilizer response. Agronomy journal 87: 420-424.

76. Frey B, Schüepp H (1993) A role of vesicular-arbuscular (VA) mycorrhizal fungi in facilitating interplant nitrogen transfer. Soil Biology and Biochemistry 25(6): 651-658.

77. Chu GX (2004) Nitrogen fixation and N transfer from peanut to rice cultivated in aerobic soil in an intercropping system and its effect on soil $\mathrm{N}$ fertility. Plant and Soil 263(1): 17-27.

78. Dubach M, Russelle MP (1994) Forage legume roots and nodules and their role in nitrogen transfer. Agronomy Journal 86: 259-266.

79. Schroth G (1995) Searching for criteria for the selection of efficient tree species for fallow improvement, with special reference to carbon and nitrogen. Fertilizer Research 42(1-3): 297-314.

80. Hardarson G, Atkins C (2003) Optimising biological N 2 fixation by legumes in farming systems. Plant and soil 252: 41-54.

81. Gupta V, Germida J (1988) Distribution of microbial biomass and its activity in different soil aggregate size classes as affected by cultivation. Soil Biology and Biochemistry 20(6): 777-786.

82. Dick R (1994) Soil enzyme activities after 1500 years of terrace agriculture in the Colca Valley, Peru. Agriculture, Ecosystems \& Environment 50(2): 123-131.

83. Alvey S (2003) Cereal/legume rotation effects on rhizosphere bacterial community structure in West African soils. Biology and Fertility of Soils 37(2): 73-82

84. B Roo KEs PC (1984) Phosphorus in the soil microbial biomass. Soil biology and biochemistry 16, 169-175.

85. Tang X (2014) Increase in microbial biomass and phosphorus availability in the rhizosphere of intercropped cereal and legumes under field conditions. Soil Biology and Biochemistry 75: 86-93.

86. Walker TS (2003) Root exudation and rhizosphere biology. Plant physiology 132: 44-51.

87. Bolton Jr H (1985) Soil microbial biomass and selected soil enzyme activities: effect of fertilization and cropping practices. Soil biology and Biochemistry 17: 297-302.
88. Goyal S (1993) Microbial biomass turnover and enzyme activities following the application of farmyard manure to field soils with and without previous long-term applications. Biology and Fertility of Soils 15(1): 60-64

89. Dick R (1988) Influence of long-term residue management on soil enzyme activities in relation to soil chemical properties of a wheatfallow system. Biology and Fertility of Soils 6(2): 159-164.

90. Li L (2007) Diversity enhances agricultural productivity via rhizosphere phosphorus facilitation on phosphorus-deficient soils. Proceedings of the National Academy of Sciences 104: 11192-11196.

91. Dalai R (1977) Soil organic phosphorus. In Advances in agronomy 83117.

92. Li H (2014) Rhizosphere properties in monocropping and intercropping systems between faba bean (Vicia faba L.) and maize (Zea mays L.) grown in a calcareous soil. Crop and Pasture Science 64: 976-984.

93. Shane MW (2006) Specialized 'dauciform'roots of Cyperaceae are structurally distinct, but functionally analogous with 'cluster'roots. Plant, Cell \& Environment 29(10): 1989-1999.

94. Li L (2004) Calcium, magnesium and microelement uptake as affected by phosphorus sources and interspecific root interactions between wheat and chickpea. Plant and Soil 261(1-2): 29-37.

95. Li H (2008) Dynamics of phosphorus fractions in the rhizosphere of common bean (Phaseolus vulgaris L.) and durum wheat (Triticum turgidum durum L.) grown in monocropping and intercropping systems. Plant and Soil 312(1-2): 139-150.

96. Tarafdar J, Jungk A (1987) Phosphatase activity in the rhizosphere and its relation to the depletion of soil organic phosphorus. Biology and Fertility of Soils 3(4): 199-204

97. Goldstein A (1992) Phosphate starvation inducible enzymes and proteins in higher plants. In Society for Experimental Biology Seminar Series 25-44.

98. Duff SM (1994) The role of acid phosphatases in plant phosphorus metabolism. Physiologia Plantarum 90(4): 791-800.

99. Del Pozo JC (1999) A type 5 acid phosphatase gene from Arabidopsis thaliana is induced by phosphate starvation and by some other types of phosphate mobilising/oxidative stress conditions. The Plant Journal 19(5): 579-589.

100. Haran S (2000) Characterization of Arabidopsis acid phosphatase promoter and regulation of acid phosphatase expression. Plant Physiology 124: 615-626.

101. Baldwin JC (2001) LEPS2, a phosphorus starvation-induced novel acid phosphatase from tomato. Plant physiology 125(2): 728-737.

102. Miller SS, Liu J, Allan DL, Menzhuber CJ, Fedorova M, et al. (2001) Molecular control of acid phosphatase secretion into the rhizosphere of proteoid roots from phosphorus-stressed white lupin. Plant Physiology 127(2): 594-606.

103. Li D, Zhu H, Liu K, Liu X, Leggewie G, et al. (2002) Purple acid phosphatases of Arabidopsis thaliana comparative analysis and differential regulation by phosphate deprivation. Journal of Biological Chemistry 277(31): 27772-27781.

104. Dick W, Tabatabai MA (1993) Significance and potential uses of soil enzymes. Soil microbial ecology: application in agricultural and environmental management. Marcel Dekker, New York, USA, p. 95-125.

105. Eivazi F, Tabatabai M (1977) Phosphatases in soils. Soil Biol Biochem 9(3): 167-172

106. Dick W (2000) Soil acid and alkaline phosphatase activity as $\mathrm{pH}$ adjustment indicators. Soil Biology and Biochemistry 32(2000): 19151919.

107. Nakas J (1987) Origin and expression of phosphatase activity in a semi-arid grassland soil. Soil Biology and Biochemistry 19(1): 13-18. 
108. Chróst RJ (1991) Environmental control of the synthesis and activity of aquatic microbial ectoenzymes. In Microbial enzymes in aquatic environments 29-59.

109. Hayes JE, (1999) Phytase and acid phosphatase activities in extracts from roots of temperate pasture grass and legume seedlings. Functional Plant Biology 26(8): 801-809.

110. Li M, Mitsuru OsakiIdupulapati, Madhusudana Rao, Toshiaki Tadano (1997) Secretion of phytase from the roots of several plant species under phosphorus-deficient conditions. Plant and soil 195(1): 161169.

111. Bariola PA (1994) The Arabidopsis ribonuclease gene RNS1 is tightly controlled in response to phosphate limitation. The Plant Journal 6(5): 673-685.

112. Muchhal US (1996) Phosphate transporters from the higher plant Arabidopsis thaliana. Proceedings of the National Academy of Sciences 93(19): 10519-10523.

113. Daram P (1999) Pht2; 1 encodes a low-affinity phosphate transporter from Arabidopsis. The Plant Cell 11: 2153-2166.

114. Kai M, Kouji Takazumi, Hirofumi Adachi, Jun Wasaki, Takuro Shinano, et al. (2002) Cloning and characterization of four phosphate transporter cDNAs in tobacco. Plant Science 163(4): 837-846.

115. Karthikeyan AS, Deepa K Varadarajan, Uthappa T Mukatira, Matilde Paino D’Urzo, Barbara Damsz, et al. (2002) Regulated expression of Arabidopsis phosphate transporters. Plant Physiology 130: 221-233.

116. Mudge SR, Rae AL, Diatloff E, Smith FW (2002) Expression analysis suggests novel roles for members of the Pht1 family of phosphate transporters in Arabidopsis. The Plant Journal 31(3): 341-353.

117. Versaw WK, Harrison MJ (2002) A chloroplast phosphate transporter PHT2; 1, influences allocation of phosphate within the plant and phosphate-starvation responses. The Plant Cell 14(8): 1751-1766.

118. Izaguirre Mayoral M, S Flores, O Carballo (2002) Determination of acid phosphatase and dehydrogenase activities in the rhizosphere of nodulated legume species native to two contrasting savanna sites in Venezuela. Biology and Fertility of Soils 35(6): 470-472.

119. Patra D, PC Brookes, K Coleman, DS Jenkinson (1990) Seasonal changes of soil microbial biomass in an arable and a grassland soil which have

\section{ISSN: 2574-1241}

DOI: 10.26717/BJSTR.2019.17.003054

Jamal Nasar. Biomed J Sci \& Tech Res

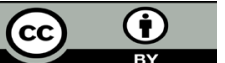

This work is licensed under Creative Commons Attribution 4.0 License

Submission Link: https://biomedres.us/submit-manuscript.php been under uniform management for many years. Soil Biology and Biochemistry 22(6): 739-742.

120. Staddon W, LC Duchesne J, T Trevors (1998) Acid phosphatase, alkaline phosphatase and arylsulfatase activities in soils from a jack pine (Pinus banksiana Lamb.) ecosystem after clear-cutting, prescribed burning, and scarification. Biology and Fertility of Soils 27(1): 1-4.

121. Wright A, Reddy K (2001) Phosphorus loading effects on extracellular enzyme activity in Everglades wetland soils. Soil Science Society of America Journal 65(2): 588-595.

122. Yadav R, Tarafdar J (2001) Influence of organic and inorganic phosphorus supply on the maximum secretion of acid phosphatase by plants. Biology and Fertility of soils 34(3): 140-143.

123. Songyin G (1989) Studies on the Factors Influencing Soil Enzyme Activities ?. Effects of Organic Manures on Soil Enzyme Activities and n, P Transfomations [J]. Acta Pedologica Sinica 1: 009.

124. Aon M, Colaneri A (2001) II. Temporal and spatial evolution of enzymatic activities and physico-chemical properties in an agricultural soil. Applied Soil Ecology 18(3): 255-270.

125. Xue Y, Xia H, Christie P, Zhang ZA, Li LY, et al. (2016) Crop acquisition of phosphorus, iron and zinc from soil in cereal/legume intercropping systems: a critical review. Annals of botany 117(3): 363-77.

126. Nel P (1975) Mixed cropping of lupines and winter cereals. Seeds yield and quality under field conditions. Journal Agricultural Science 8: 219237.

127. Willey R (1990) Resource use in intercropping systems. Agricultural water management 17(1-3): 215-231.

128. Morris R, Garrity D (1993) Resource capture and utilization in intercropping; non-nitrogen nutrients. Field Crops Research 34(3-4): 319-334.

129. Mpairwe D (2002) Effect of intercropping cereal crops with forage legumes and source of nutrients on cereal grain yield and fodder dry matter yields. African Crop Science Journal 10(1): 81-97.

130. Crews T, Peoples M (2004) Legume versus fertilizer sources of nitrogen: ecological tradeoffs and human needs. Agriculture, ecosystems \& environment 102(3): 279-297.

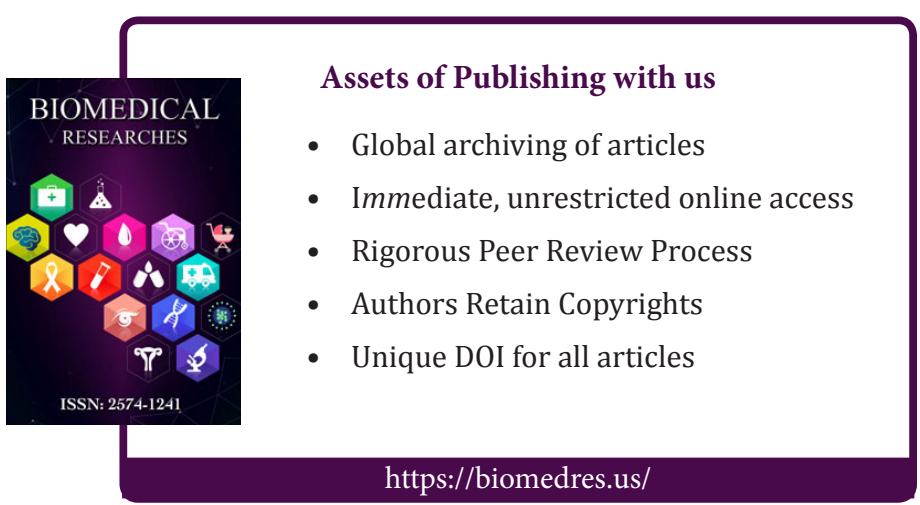

